\title{
Article \\ Influence of Digester Temperature on Methane Yield of Organic Fraction of Municipal Solid Waste (OFMSW)
}

\author{
Gregor Sailer ${ }^{1, *(\mathbb{D}}$, Martin Silberhorn ${ }^{1}$, Johanna Eichermüller ${ }^{1}$, Jens Poetsch ${ }^{1}$, Stefan Pelz ${ }^{1}\left(\mathbb{C}\right.$, Hans Oechsner ${ }^{2}(\mathbb{C})$ \\ and Joachim Müller ${ }^{3}$ (i)
}

check for

updates

Citation: Sailer, G.; Silberhorn, M.; Eichermüller, J.; Poetsch, J.; Pelz, S.; Oechsner, H.; Müller, J. Influence of Digester Temperature on Methane Yield of Organic Fraction of Municipal Solid Waste (OFMSW). Appl. Sci. 2021, 11, 2907. https:// doi.org/10.3390/app11072907

Academic Editor: Carlos Rico de la Hera

Received: 8 March 2021

Accepted: 22 March 2021

Published: 24 March 2021

Publisher's Note: MDPI stays neutral with regard to jurisdictional claims in published maps and institutional affiliations.

Copyright: (C) 2021 by the authors. Licensee MDPI, Basel, Switzerland. This article is an open access article distributed under the terms and conditions of the Creative Commons Attribution (CC BY) license (https:// creativecommons.org/licenses/by/ $4.0 /)$.
1 Department of Bioenergy, University of Applied Forest Sciences Rottenburg, Schadenweilerhof, 72108 Rottenburg, Germany; marsilb@web.de (M.S.); eichermueller@hs-rottenburg.de (J.E.); poetsch@hs-rottenburg.de (J.P.); pelz@hs-rottenburg.de (S.P.)

2 State Institute of Agricultural Engineering and Bioenergy, University of Hohenheim, Garbenstrasse 9, 70599 Stuttgart, Germany; hans.oechsner@uni-hohenheim.de

3 Tropics and Subtropics Group, Institute of Agricultural Engineering, University of Hohenheim, Garbenstrasse 9, 70599 Stuttgart, Germany; joachim.mueller@uni-hohenheim.de

* Correspondence: sailer@hs-rottenburg.de or sbc@hs-rottenburg.de

\begin{abstract}
This study evaluates the anaerobic digestion (AD) of the organic fraction of municipal solid waste (OFMSW) and digested sewage sludge (DSS) at lowered temperatures. AD batch tests for $\mathrm{CH}_{4}$ yield determination were carried out with DSS as inoculum between 23 and $40{ }^{\circ} \mathrm{C}$. All results were related to organic dry matter and calculated for standard conditions $\left(1013 \mathrm{hPa}, 0{ }^{\circ} \mathrm{C}\right)$. The AD experiments at $40^{\circ} \mathrm{C}$ and at $35^{\circ} \mathrm{C}$ delivered specific $\mathrm{CH}_{4}$ yields of $325 \pm 6 \mathrm{~mL} / \mathrm{g}$ and $268 \pm 27 \mathrm{~mL} / \mathrm{g}$ for OFMSW alone. At lower temperatures, specific $\mathrm{CH}_{4}$ yields of $364 \pm 25 \mathrm{~mL} / \mathrm{g}\left(25^{\circ} \mathrm{C}\right)$ and $172 \pm 21 \mathrm{~mL} / \mathrm{g}\left(23{ }^{\circ} \mathrm{C}\right)$ were reached. $\mathrm{AD}$ at $25^{\circ} \mathrm{C}$ could be beneficial regarding energy input (heating costs) and energy output $\left(\mathrm{CH}_{4}\right.$ yield). Plant operators could increase AD efficiencies by avoiding heating costs. The co-digestion of OFMSW together with DSS could lead to further synergies such as better exploitation of the energy potentials of DSS, but the digestate utilization could become problematic due to hygienic requirements. Efficiency potentials through lowered operating temperatures are limited. In further research, lowered process temperatures could be applied in the AD of energy crops due to large numbers of existing plants.
\end{abstract}

Keywords: OFMSW; digested sewage sludge; waste characterization; anaerobic digestion; operating temperature; mesophilic; psychrophilic

\section{Introduction}

The global municipal solid waste (MSW) generation forecast for 2025 is about 2200 million tons. Consequent to that, the organic fraction of municipal solid waste (OFMSW) is estimated to be $46 \%$ [1]. In 2015, 241 million tons of MSW with a share of $40-60 \%$ of organics were generated in the EU [2]. If OFMSW is not collected and treated separately and instead disposed of in landfills with other MSW components; degradation processes such as anaerobic digestion (AD) occur underground, producing several environmental damages such as greenhouse gas (GHG) emissions or hazardous substances causing health hazards. Therefore, reduction targets for landfilling of MSW and OFMSW in the EU have been defined and further developed since the late 1990s. In addition, the separate collection and treatment of OFMSW via AD or composting have been promoted. EU-wide, landfilling is declining but still relevant, while the depositing of untreated MSW and OFMSW is already forbidden in Germany [3-5].

Composting of OFMSW leads to GHG emissions in the form of $\mathrm{CO}_{2}$ released directly into the atmosphere and can cause unpleasant odors. Due to the generation of renewable energy, AD of OFMSW is indicated with a better GHG balance, compared to composting, and odor problems are easier to control [1,2,6-11]. $\mathrm{CH}_{4}$ generated in the AD of OFMSW 
can be used in various applications (e.g., combined heat and power or fuel) and represents a storable energy carrier [1]. AD and composting can be combined to exploit the material and energetic utilization potentials of OFMSW fully. The utilization of OFMSW via AD is in the sense of the circular economy according to the EU agenda, which envisages keeping products and materials in the market for as long as possible. However, the improvement of $\mathrm{AD}$ as a major component of future energy systems is the focus of politics and research facilities [1,12,13]. AD helps to achieve several of the UN sustainable development goals [14] by producing clean and affordable energy, contributing to sustainable municipalities, and supporting climate protection [15].

OFMSW is not the only waste material with untapped potentials for the generation of renewable energy. Worldwide, the $\mathrm{CH}_{4}$ potentials for residues from crops (3080-3920 TWh), manure (2600-3800 TWh), food waste (880-1100 TWh), or sewage sludge (210-300 TWh) can be exploited on a larger scale via AD $[2,15]$.

\subsection{OFMSW as a Resource}

OFMSW is an inhomogeneous mixture with characteristics depending on its origin. The composition varies in its proportions of biodegradable and non-biodegradable organics, and mineral components [1]. The different composition depends on the season, lifestyle, waste management regulations, and regional economic frameworks [16-18]. The organic fraction of the MSW is larger in lower-income countries than in higher-income countries [19]. The fluctuations in the composition of OFMSW are also reflected in the material properties. While dry matter (DM) contents of OFMSW collected from 22 different countries fluctuate between $15.0-50.2 \%$ fresh mass (FM) with a mean value of $27.2 \pm 7.6 \% \mathrm{FM}$, contents for organic dry matter (oDM) vary between 7.4-36.1\% FM (mean $22.9 \pm 6.3 \%$ FM), which is equal to $43.0-95.0 \% \mathrm{DM}$ (mean $84.6 \pm 9.9 \% \mathrm{DM}$ ). The average concentrations for $\mathrm{C}$ $(46.6 \pm 4.4 \% \mathrm{DM}), \mathrm{H}(6.6 \pm 0.62 \% \mathrm{DM}), \mathrm{N}(2.9 \pm 0.6 \% \mathrm{DM})$, and $\mathrm{S}(0.3 \pm 0.26 \% \mathrm{DM})$ are also specified, and the potential $\mathrm{CH}_{4}$ yields at standard conditions fluctuate between 61 and $580 \mathrm{~L} / \mathrm{kg}_{\mathrm{oDM}}$ with an average of $415 \pm 138 \mathrm{~L} / \mathrm{kg}_{\mathrm{oDM}}[1]$.

Due to the variety of ingredients and changing characteristics, OFMSW can serve as a resource for several treatments and utilization pathways, e.g., the share of biodegradable components in OFMSW is relevant for $\mathrm{CH}_{4}$ generated in AD [7]. Furthermore, OFMSW represents a resource for the creation of value-added products such as organic fertilizers, biopesticides, and bioplastics [2]. In general, OFMSW can be recovered with technologies using biochemical, thermochemical, or physicochemical principles, either as single technology or in combination.

\subsection{Operating Temperatures in $A D$}

AD processes can operate at different temperature levels but definitions of temperature ranges and process optima vary in the literature (Table 1). As can be seen in Table 1, a clear classification is difficult and the gaps between the temperature levels imply smooth transitions. However, according to Fritsche and Laplace [20] and Munk et al. [21], process temperatures in AD can be subdivided into four different ranges, namely, psychrophilic $\left(12-15^{\circ} \mathrm{C}\right)$, psychrotolerant $\left(20-30{ }^{\circ} \mathrm{C}\right)$, mesophilic $\left(30-40{ }^{\circ} \mathrm{C}\right)$ and thermophilic $\left(55-75^{\circ} \mathrm{C}\right)$. In general, microorganisms with a metabolism based on AD are known to exist in a temperature range of $-5-121^{\circ} \mathrm{C}$. Microorganisms between 70 and $85^{\circ} \mathrm{C}$ are called extremely thermophilic, while the temperature range from $85-121^{\circ} \mathrm{C}$ is described as hyper-thermophilic [22]. Although the higher activity of the methanogenic microorganisms at thermophilic temperature leads to a higher degradation rate and higher biogas yields, the process stability is more sensitive, and maintaining process temperatures requires more energy, which reduces the total energy yield [23-27]. An additional advantage of thermophilic process temperatures is a lower level of sludge generation and the possibility to fulfill hygienic requirements (e.g., regulated by the German Biowaste Ordinance) for substrates such as OFMSW that need hygienic treatment [22,28]. Therefore, usually, no separate sanitation systems are required at thermophilic AD plants. 
Table 1. Temperature ranges and optima in technical anaerobic digestion processes according to different studies.

\begin{tabular}{|c|c|c|c|c|}
\hline Reference & Year & $\begin{array}{c}\text { Psychrophilic } \\
\left({ }^{\circ} \mathrm{C}\right)\end{array}$ & Mesophilic $\left({ }^{\circ} \mathrm{C}\right)$ & Thermophilic $\left({ }^{\circ} \mathrm{C}\right)$ \\
\hline Zábranská et al. [29] & 2000 & - & $30-40$ & $50-70$ \\
\hline Ahring et al. [30] & 2001 & - & - & $55-70$ \\
\hline Kashyap et al. [31] & 2003 & $<20$ & $32-38$ & $50-55$ \\
\hline Connaughton et al. [32] & 2006 & $<20$ & $25-45$ & $45-65$ \\
\hline Reichard [10] & 2006 & & $<50$ & $>50$ \\
\hline LfU [33] & 2007 & $<20$ & $30-42$ & $48-55$ \\
\hline Effenberger et al. [34] & 2008 & $<25$ & $32-42$ & $50-57$ \\
\hline Vindis et al. [27] & 2009 & $12-16$ & $35-37$ & $55-60$ \\
\hline Amon et al. [35] & 2013 & $<25$ & $37-42$ & $50-60$ \\
\hline Donoso-Bravo et al. [36] & 2013 & $15-25$ & $35-37$ & $50-55$ \\
\hline Jain et al. [26], Fernández-Rodríguez et al. [37] & 2015,2013 & - & 35 & 55 \\
\hline Szyłak-Szydłowski et al. [38] & 2016 & - & $35-37$ & - \\
\hline Kaltschmitt et al. [22] & 2016 & $<25$ & $35-42$ & $50-55$ \\
\hline Liu et al. [39] & 2016 & - & $25-37$ & $55-65$ \\
\hline Chala et al. [40] & 2019 & $<20$ & $20-45$ & $45-60$ \\
\hline Jain et al. [15] & 2019 & - & $35-40$ & $55-60$ \\
\hline Kumar and Samadder [41] & 2020 & $\sim 20$ & $\sim 35$ & $\sim 55$ \\
\hline Rocamora et al. [9] & 2020 & - & $35-40$ & $50-57$ \\
\hline Jaimes-Estévez et al. [42] & 2020 & $<20$ & $20-45$ & - \\
\hline Lanko et al. [43] & 2020 & - & $35-40$ & $55-70$ \\
\hline Pasalari et al. [44] & 2021 & $9-25$ & $25-35$ & $35-70^{1}$ \\
\hline
\end{tabular}

${ }^{1}$ subdivided into thermophilic $\left(35-55^{\circ} \mathrm{C}\right)$ and extreme-thermophilic $\left(55-70{ }^{\circ} \mathrm{C}\right)$.

Cavinato et al. [45] discovered that biogas yields via thermophilic $\mathrm{AD}\left(55^{\circ} \mathrm{C}\right)$ of OFMSW together with sewage sludge can be $45-50 \%$ higher compared to mesophilic AD $\left(37^{\circ} \mathrm{C}\right)$. Derbal et al. [46] already investigated the influence of mesophilic $\left(35^{\circ} \mathrm{C}\right)$ and thermophilic $\left(55^{\circ} \mathrm{C}\right) \mathrm{AD}$ of OFMSW on the biogas quantity and quality with a hydraulic retention time (HRT) of $25 \mathrm{~d}$. In this case, the mesophilic AD was less efficient than the thermophilic AD. Fernández-Rodríguez et al. [37] confirmed these results.

Mesophilic AD is indicated with higher process stability than thermophilic AD through greater diversity of microorganisms, and with lower resistance to foaming and lower organic loading rates. At mesophilic temperature, the amount of $\mathrm{CO}_{2}$ in the biogas is reduced as a higher percentage remains dissolved in the liquid phase, but the conversion rate of cellulose and hemicellulose is lower than in thermophilic AD. Lower process temperatures lead to lower energy demands of AD plants and offer the possibility to use low-temperature waste heat for process heating [22,23,27,47].

Rajagopal et al. [48] proved that psychrophilic AD is indicated with high process stability, which was also confirmed by other studies $[49,50]$. At the psychrophilic level, the additional energy input to maintain $\mathrm{AD}$ temperature is reduced or nullified depending on the ambient temperatures [32]. The comparatively slow $\mathrm{CH}_{4}$ generation in $\mathrm{AD}$ at lower temperatures can be compensated by larger digester volumes and an increased HRT, reaching similar final $\mathrm{CH}_{4}$ yields (tested with coffee husks, pulp, and mucilage) to those of mesophilic $\mathrm{AD}[40,51]$. Connaughton et al. [32] also concluded that the total $\mathrm{CH}_{4}$ yields of mesophilic $\mathrm{AD}\left(37^{\circ} \mathrm{C}\right)$ of brewery wastewater are similar to the yields in psychrophilic $\mathrm{AD}\left(15^{\circ} \mathrm{C}\right)$. With lower temperatures, the $\mathrm{CH}_{4}$ concentrations in the biogas increase. Liu et al. [39] proved that the psychrophilic $\mathrm{AD}\left(15^{\circ} \mathrm{C}\right)$ of sewage sludge delivered approximately half of the $\mathrm{CH}_{4}$ yield, compared to the $\mathrm{AD}$ at $30^{\circ} \mathrm{C}$ at the same time step. The finding of Kashyap et al. [31], i.e., AD processes at psychrophilic temperature level require an HRT roughly twice as long to achieve the same $\mathrm{CH}_{4}$ yield, underlines the findings of Liu et al. [39] and Chala et al. [40].

Anaerobic microorganisms can adapt to different temperatures, but the specific methanogenic activity, and thus the $\mathrm{CH}_{4}$ production, decreases proportionally to process temperature $[25,31,52]$. Other studies $[30,53]$ complement this correlation. It was 
found that an increased process temperature (up to $55^{\circ} \mathrm{C}$ ) leads to an increased $\mathrm{CH}_{4}$ yield in the $\mathrm{AD}$ of cattle manure. However, further increased $\mathrm{AD}$ temperatures $\left(65^{\circ} \mathrm{C}\right)$ lead to a reduction in $\mathrm{CH}_{4}$ yields. This can be explained by findings of other studies $[53,54]$ in which it was found that the diversity of microorganisms decreases with increasing AD temperatures. Therefore, $\mathrm{CH}_{4}$ yield increases through heightened process temperatures are limited (e.g., the $\mathrm{CH}_{4}$ yield of waterweed was halved at $65^{\circ} \mathrm{C}$, compared to $55^{\circ} \mathrm{C}$ ). The diversity of methanogenic organisms also decreases at low $\mathrm{AD}$ temperatures, e.g., when reducing the process temperature from 37 to $15^{\circ} \mathrm{C}$ [55].

\subsection{AD of OFMSW}

OFMSW can be digested in dry AD processes at DM contents $>15-20 \%$ FM or wet AD processes at DM contents $<15-20 \%$ FM. Luning et al. [56] found that the same $\mathrm{CH}_{4}$ yields can be achieved in practice with wet and dry AD processes, which was also confirmed by Rajagopal et al. [57] and Kern and Raussen [58]. OFMSW, in its natural state, is indicated with a DM content $>20 \%$ and complex composition, including substances such as lignin that hardly contribute to biogas yields. Therefore, it is often digested in dry processes such as plug-flow or batch digesters. If OFMSW is used in wet processes (e.g., via stirred tank reactors), it has to be diluted to a pumpable condition through its mixture with other substrates or water $[1,22]$.

On a global level, biowaste (e.g., food waste as a component of OFMSW) is mostly digested at mesophilic temperatures in wet $\mathrm{AD}$ plants [15]. Due to the simpler construction of an unheated psychrophilic biogas plant, this method is currently an important form of supplying $\mathrm{CH}_{4}$ in developing countries and emerging economies. Micro digesters (household size) can be found millions of times in China (42 million, but also $7000 \mathrm{AD}$ plants with an electrical capacity of approximately 0.1-1 MW), India (5 million), and Africa, along with other Asian countries ( 0.7 million). The generated biogas is mostly used for cooking stoves $[15,19,59]$. In other regions of the world, micro digesters are barely used, and large(r) scale biogas plants are common., e.g., 2200 biogas plants operate in the USA with an installed total capacity of $977 \mathrm{MW}$, leading to an average plant size of approximately $0.45 \mathrm{MW}$. Including landfill and sewage AD plants, approximately 17,800 AD plants with an installed electrical capacity of $10.5 \mathrm{GW}$ operate in the EU out of which approximately 700 are utilizing OFMSW and industrial biowaste. An increase in the number of biogas plants for OFMSW and industrial biowaste is expected as a separate collection of OFMSW is envisaged EU-wide $[15,19]$.

By 2018, approximately 9500 biogas plants with an installed electrical capacity of $5 \mathrm{GW}$ were operated in Germany, mainly based on energy crops [60,61]. Most agricultural biogas plants are equipped with stirred tank reactors at mesophilic temperatures with defined feeding intervals. The generated biogas is mostly used for the combined generation of electricity and heat. In the currently operating approximately 215 biogas plants, biogas is upgraded to biomethane and fed into the gas grid. Psychrophilic biogas plants are uncommon in Germany [22,58,62]. In 2015, 1392 biogas plants in Germany were registered to use biowaste as feedstock, but only 337 actually used it as the main substrate or in co-digestion. Then, again, 75 biogas plants are specialized on OFMSW (share of OFMSW compared to the total feedstock $>90 \%$ ) operating as dry AD system at a thermophilic and mesophilic temperature in equal share [58,60].

According to the literature [63-65], the heat demand of AD systems depends on substrate characteristics, operating temperature, and geographic region, and on AD parameters such as digester type or plant size. The benchmarking of German biogas plants [65] has proven that heat demands for digester heating can be between 0 and $100 \%$ of the generated heat. Especially small biogas plants with an electrical capacity below $150 \mathrm{~kW}$ and plants utilizing substrates with high water contents show higher heat demands. Typically, the digester heating demand is $30 \pm 20 \%$ of the generated heat. A lower digester heating demand would allow heat export, and hence the profitability of biogas plants could be increased. 


\subsection{Aim of the Study}

Currently, typical digester temperatures of OFMSW biogas plants are at mesophilic or thermophilic levels, causing a high heating demand [58]. The aim of this study was therefore to investigate the influence of lower-process temperatures on the quantity and quality of biogas generated from OFMSW. The main objective was to determine whether it is possible to increase the efficiency of OFMSW biogas plants by avoiding heating demands without losing energy yields. Another objective was to determine whether the combined treatment of OFMSW and DSS, which was used as inoculum, could create synergies in a wet digestion system due to large numbers of existing wastewater plants and infrastructures.

\section{Materials and Methods}

\subsection{Substrate Characteristics}

All analytic procedures were performed at the University of Applied Sciences, Rottenburg, following VDI 4630 [66] and corresponding standards.

\subsubsection{Sampling of OFMSW and Digested Sewage Sludge (DSS)}

The feedstock for AD experiments was untreated OFMSW collected at a full-scale biowaste AD plant in southern Germany processing exclusively OFMSW. Sampling was conducted in accordance with the German Biowaste Ordinance [67]. The samples were collected with a spade from a heap stored no longer than $24 \mathrm{~h}$ in a closed hall. The heap was subdivided into 12 equal parts, leading to 12 sampling points out of which approximately $0.5 \mathrm{~L}$ were collected while discarding the upper waste layer. The resulting single samples were merged into one bulk sample (10.5 kg FM). To avoid uncontrolled degradation processes, the sample was transported and further processed within $2 \mathrm{~h}$ after collection.

The inoculum used for AD experiments was DSS collected at the local municipal sewage treatment plant (Rottenburg-Kiebingen, Germany), where wastewater is treated via aerobic and anaerobic steps. The terms inoculum and DSS are used synonymously in this study. DSS is regarded as suitable inoculum for AD experiments because it contains a large number of different microorganisms [66]. Each sample collection followed the same procedure [66]. The sampling was conducted in November (series 1) and in February (series 2) from the outlet valve of the digestate container where the DSS is stored at $37^{\circ} \mathrm{C}$. The digestate container also serves as a secondary digester with an identical temperature level compared to the main $\mathrm{AD}$ unit. However, the digestate container is operated with a low HRT. It mainly serves as a buffer prior to the solid-liquid separation of the DSS. To date, the additional biogas yields are marginal but still used in the combined heat and power unit at the treatment plant. After opening the outlet valve, the first approximately $10 \mathrm{~L}$ were discarded. The samples were filled into two 30-L buckets, closed airtight for transportation, and handled within $1 \mathrm{~h}$ to avoid excess cooling and contact with ambient air.

\subsubsection{DM, oDM, and Processing}

DM contents were determined according to the German Biowaste Ordinance [68] through drying at $105{ }^{\circ} \mathrm{C}$ in a drying oven (UNP 700, Memmert, Schwabach, Germany) for at least $24 \mathrm{~h}$. Before further processing, impurities (stones, metal, glass, plastics) in the OFMSW bulk sample were removed, and the remaining DM was milled in a cutting mill (Pulverisette 19, Fritsch, Idar-Oberstein, Germany) to particle sizes of approximately $1 \mathrm{~mm}$. To achieve homogeneous particle sizes, the dry inoculum was manually crushed in a ceramic mortar; prior sorting was not required. Afterward, oDM was determined for each sample in minimum triplicate [69] through incineration of approximately $1 \mathrm{~g}$ DM in a ceramic crucible by a muffle furnace (AAF 1100, Carbolite, Neuhausen, Germany). This procedure [69] slightly differed from the method mentioned in the German Biowaste Ordinance [70] and was chosen due to the availability of a preprogrammed automatic furnace. 


\subsubsection{Elemental Analysis and Stoichiometric Biogas Potentials}

The determination of $\mathrm{C}, \mathrm{H}$, and $\mathrm{N}$ was carried out with an elemental analyzer (vario MACRO cube, Elementar, Langenselbold, Germany) in a minimum of four replicates per sample [71]. Each sample (approximately $40 \mathrm{mg} \mathrm{DM}$ ) was pressed into a zinc foil-coated tablet. Stoichiometric biogas and $\mathrm{CH}_{4}$ yields were calculated according to Equation (1) [72,73] and related to standard conditions. O contents were calculated based on the mean values for $\mathrm{C}$, $\mathrm{H}, \mathrm{N}$, and ash. $\mathrm{S}$ was neglected in the calculations. Therefore, the stoichiometric biogas yield equaled the sum of all products except $\mathrm{H}_{2} \mathrm{~S}$ (which slightly reduced the biogas yields).

$$
\begin{aligned}
\mathrm{C}_{n} \mathrm{H}_{a} \mathrm{O}_{b} \mathrm{~N}_{c} \mathrm{~S}_{d}+\left(n-\frac{a}{4}-\frac{b}{2}\right. & \left.+\frac{3}{4} c+\frac{d}{2}\right) \mathrm{H}_{2} \mathrm{O} \rightarrow\left(\frac{n}{2}-\frac{a}{8}+\frac{b}{4}+\frac{3}{8} c-\frac{d}{4}\right) \mathrm{CO}_{2} \\
& +\left(\frac{n}{2}+\frac{a}{8}-\frac{b}{4}-\frac{3}{8} c-\frac{d}{4}\right) \mathrm{CH}_{4}+c \mathrm{NH}_{3}+d \mathrm{H}_{2} \mathrm{~S} .
\end{aligned}
$$

\subsection{AD Experiments and Process Monitoring}

Biochemical methane potential tests were carried out according to VDI 4630 [66]. The volumetric biogas production was measured using glass manometers (1-L gas storage) considering the temperature within the digester and ambient conditions. The biogas composition was analyzed with portable biogas monitors (BIOGAS 5000 and GAS 5000, Geotech, Coventry, UK) from biogas collected and stored in bags (PLASTIGAS, Linde, Pullach, Germany). The specific biogas and $\mathrm{CH}_{4}$ production were related to oDM and calculated for standard conditions $\left(1013 \mathrm{hPa}, 0{ }^{\circ} \mathrm{C}\right.$, dry gas). The configuration of each digester, the installed gas measurement system, and the storage bag as used in this study is depicted in Sailer et al. [74].

The experiments were conducted in two batch test series at $25 / 40{ }^{\circ} \mathrm{C}$ and at $23 / 35^{\circ} \mathrm{C}$ using 2-L insulated glass vessels with preprogrammed heating, which were automatically stirred for $60 \mathrm{~s} / \mathrm{h}$. In each test series, 12 digesters were used (thereof four blank variants). The operating temperature of 35 and $40{ }^{\circ} \mathrm{C}$ was selected to represent typical German mesophilic biogas processes. The lowered operating temperature of $25^{\circ} \mathrm{C}$ in the first test series was chosen in order to achieve an adequate reduction of the heat demand and in order to remain close to the mesophilic temperature level (Table 1). The temperature of $23{ }^{\circ} \mathrm{C}$ was the lowest possible temperature in the laboratory. It was therefore chosen in the second test series. The detailed experimental setup is provided in Table 2.

Table 2. Experimental setup of the anaerobic digestion experiments of both test series at $25 / 40{ }^{\circ} \mathrm{C}$ and $23 / 35^{\circ} \mathrm{C}$. Digested sewage sludge (DSS) was used as inoculum (Inoc.), while dry matter (DM) of the organic fraction of municipal solid waste

\begin{tabular}{|c|c|c|c|c|c|c|c|c|}
\hline \multirow[b]{2}{*}{ Variant } & \multicolumn{2}{|c|}{ Series 1 T25 } & \multicolumn{2}{|c|}{ Series 1 T40 } & \multicolumn{2}{|c|}{ Series 2 T23 } & \multicolumn{2}{|c|}{ Series 2 T35 } \\
\hline & $\begin{array}{c}\text { Inoc. } \\
\text { (blank) }\end{array}$ & $\begin{array}{l}\text { Inoc. and } \\
\text { OFMSW }\end{array}$ & $\begin{array}{c}\text { Inoc. } \\
\text { (blank) }\end{array}$ & $\begin{array}{l}\text { Inoc. and } \\
\text { OFMSW }\end{array}$ & $\begin{array}{c}\text { Inoc. } \\
\text { (blank) }\end{array}$ & $\begin{array}{l}\text { Inoc. and } \\
\text { OFMSW }\end{array}$ & $\begin{array}{c}\text { Inoc. } \\
\text { (blanc) }\end{array}$ & $\begin{array}{l}\text { Inoc. and } \\
\text { OFMSW }\end{array}$ \\
\hline Inoculum & 0.8 L DSS & 2 L DSS & 0.8 L DSS & $2 \mathrm{~L}$ DSS & 1 L DSS & 1 L DSS & 1 L DSS & 1 L DSS \\
\hline & $1.2 \mathrm{~L}$ water & & $1.2 \mathrm{~L}$ water & & $1 \mathrm{~L}$ water & $1 \mathrm{~L}$ water & $1 \mathrm{~L}$ water & $1 \mathrm{~L}$ water \\
\hline Feedstock & - & $\begin{array}{l}15 \mathrm{~g} \text { DM } \\
\text { OFMSW }\end{array}$ & - & $\begin{array}{l}15 \text { g DM } \\
\text { OFMSW }\end{array}$ & - & $\begin{array}{l}10 \text { g DM } \\
\text { OFMSW }\end{array}$ & - & $\begin{array}{l}10 \text { g DM } \\
\text { OFMSW }\end{array}$ \\
\hline $\begin{array}{c}\text { Retention } \\
\text { time (d) }\end{array}$ & 56 & 56 & 56 & 56 & 77 & 77 & 35 & 35 \\
\hline $\begin{array}{c}\text { Day with gas } \\
\text { analysis }\end{array}$ & 56 & $5 ; 56$ & 56 & $5 ; 56$ & $8 ; 24$ & $8 ; 24$ & $8 ; 24$ & $8 ; 24$ \\
\hline Replicates & 2 & 4 & 2 & 4 & 2 & 4 & 2 & 4 \\
\hline
\end{tabular}
(OFMSW) served as feedstock.

In the first test series, the biogas composition was measured on day 5 (only variants with OFMSW as feedstock) and day 56 (all digesters). In the second test series, the biogas measurements of day 24 were used to extrapolate the $\mathrm{CH}_{4}$ yield results. Therefore, the measured biogas yields ( $\left.\mathrm{mL} / \mathrm{g}_{\mathrm{oDM}}\right)$ from day 25 to days 35 and 77 were transferred to $\mathrm{CH}_{4}$ yields (mL/goDM) based on the $\mathrm{CH}_{4}$ concentration (\%) measured on day 24 . This 
procedure had to be conducted in accordance with SARS-CoV-2 laboratory regulations (limited laboratory access).

The inoculum was added without further degassing (already treated anaerobically at the treatment plant). However, blind variants were carried out in duplicate, determining the residual biogas potential of the DSS. According to VDI 4630 [66], DSS contains a broad variety of microorganisms. Therefore, all digesters started with the same initial conditions at $37^{\circ} \mathrm{C}$, reaching the designated operating temperature several hours later (no long-time acclimation period for microorganisms was executed). In variants with added tap water, the water was preheated to $37^{\circ} \mathrm{C}$. The experiments were stopped as soon as the biogas formation rate per digester remained close to $1 \mathrm{~mL} / \mathrm{h}$. Only the digesters at $23^{\circ} \mathrm{C}$ (unheated) were operated with an increased retention time (approximately doubled compared to the digesters at $35^{\circ} \mathrm{C}$ ). For both test series, the same OFMSW sample was used. The specific biogas yield of the mixture of OFMSW and DSS in each digester (Table 2) was calculated as

$$
S B G_{O F M S W} \text { and DSS }=\frac{B G_{O F M S W} \text { and } D S S}{m_{O D M, O F M S W}+m_{O D M, D S S}},
$$

where $S B G_{O F M S W}$ and $D S S\left(\mathrm{~mL} / \mathrm{g}_{\mathrm{oDM}}\right)$ is the specific biogas yield from the mixture of OFMSW and DSS, $B G_{O F M S W}$ and DSS $(\mathrm{mL})$ is the total gas yield from the mixture of OFMSW and DSS (used as inoculum), and $m_{O D M, O F M S W}$ and $m_{O D M, D S S}\left(\mathrm{~g}_{\mathrm{ODM}}\right)$ are the organic mass of OFMSW and DSS, respectively.

The specific biogas yield of OFMSW alone was calculated as

$$
S B G_{O F M S W}=\frac{B G_{O F M S W} \text { and } D S S}{m_{O D M, O F M S W}}-B G_{D S S},
$$

where $S B G_{O F M S W}\left(\mathrm{~mL} / \mathrm{g}_{\mathrm{ODM}}\right)$ is the specific biogas yield from OFMSW alone, and $B G_{D S S}$ $(\mathrm{mL})$ is the biogas yield from DSS, i.e., from the corresponding blanks.

The specific $\mathrm{CH}_{4}$ yield of the mixture of OFMSW and DSS was calculated as

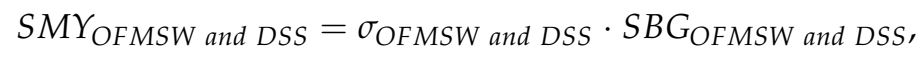

where $S M Y_{\text {OFMSW and DSS }}\left(\mathrm{mL} / \mathrm{g}_{\mathrm{oDM}}\right)$ is the specific $\mathrm{CH}_{4}$ yield from the mixture of OFMSW and DSS, and $\sigma_{\text {OFMSW and DSS }}(-)$ is the measured volume concentration of $\mathrm{CH}_{4}$ in the biogas from the mixture.

The specific $\mathrm{CH}_{4}$ yield of the blanks was calculated as

$$
S M Y_{D S S}=\sigma_{D S S} \cdot S B G_{D S S},
$$

where $S M Y_{D S S}\left(\mathrm{~mL} / \mathrm{g}_{\mathrm{oDM}}\right)$ is the specific $\mathrm{CH}_{4}$ yield from DSS (blanks), $S B G_{D S S}\left(\mathrm{~mL} / \mathrm{g}_{\mathrm{oDM}}\right.$ ) is the specific biogas of the DSS, and $\sigma_{\text {DSS }}(-)$ is the measured volume concentration of $\mathrm{CH}_{4}$ in the biogas from the blanks.

Finally, the specific $\mathrm{CH}_{4}$ yield of OFMSW alone was calculated as

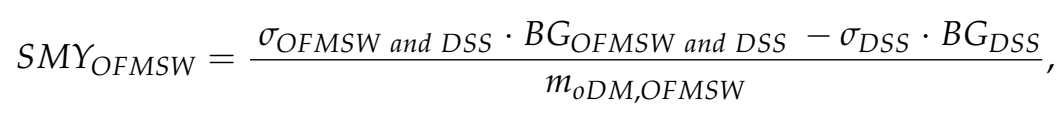

where $S M Y_{O F M S W}\left(\mathrm{~mL} / \mathrm{g}_{\mathrm{oDM}}\right)$ is the specific $\mathrm{CH}_{4}$ yield from OFMSW alone.

In experiments with two subsequent gas analyses (Table 2), measured $\mathrm{CH}_{4}$ concentrations have been applied for the corresponding time interval. For all experiments, $S M Y_{D S S}$, $S M Y_{O F M S W}$, and SMY $Y_{O F M S W}$ and DSS results were plotted based on mean values $(\mathrm{n}=2$ for DSS variants, $\mathrm{n}=4$ for variants containing OFMSW and DSS) on day 35 in order to evaluate the goodness of fit. The coefficient of determination $\left(R^{2}\right)$ was determined with the help of a linear regression line. 


\section{Results and Discussion}

\subsection{Characteristics of Raw OFMSW and DSS}

In Table 3, basic substrate characteristics are compiled, serving as a basis for all $\mathrm{AD}$ experiments and for stoichiometric biogas and $\mathrm{CH}_{4}$ yield calculations. The FM of the OFMSW sample was dried in separate fractions causing high standard deviations (SD), which was not relevant for this study. DM, oDM, and C, H and N contents of OFMSW are in line with the ranges presented in Campuzano and González-Martínez [1]. However, the DM and oDM contents, in particular, depend on various factors such as season or settlement structure. This is also represented by Campuzano and González-Martínez [1] with oDM contents for OFMSW of $84.24 \pm 10.09 \%$ DM.

Table 3. Dry matter content (DM), organic dry matter content (oDM), chemical elements of digested sewage sludge (DSS) used as inoculum, and organic fraction of municipal solid waste (OFMSW) used as substrate; mean values \pm standard deviation.

\begin{tabular}{|c|c|c|c|c|c|c|}
\hline Material & $\begin{array}{c}\text { DM } \\
(\% \text { FM) }\end{array}$ & $\begin{array}{c}\text { oDM } \\
\text { (\% DM) }\end{array}$ & $\begin{array}{c}C \\
(\% \mathrm{DM})\end{array}$ & $\begin{array}{c}\mathrm{H} \\
(\% \mathrm{DM})\end{array}$ & $\begin{array}{c}\mathrm{N} \\
(\% \mathrm{DM})\end{array}$ & $\begin{array}{c}\mathrm{O} \\
(\% \mathrm{DM})\end{array}$ \\
\hline DSS, series 1 & $\begin{array}{c}3.33 \\
\pm 1.84\end{array}$ & $\begin{array}{l}58.55 \\
\pm 0.40\end{array}$ & n.a. ${ }^{1}$ & n.a. ${ }^{1}$ & n.a. ${ }^{1}$ & n.a. ${ }^{1}$ \\
\hline DSS, series 2 & $\begin{array}{c}4.07 \\
\pm 0.01\end{array}$ & $\begin{array}{l}60.21 \\
\pm 0.17\end{array}$ & $\begin{array}{l}30.38 \\
\pm 0.11\end{array}$ & $\begin{array}{c}4.50 \\
\pm 0.06\end{array}$ & $\begin{array}{c}4.11 \\
\pm 0.04\end{array}$ & 21.22 \\
\hline OFMSW, series 1 and 2 & $\begin{array}{l}33.28 \\
\pm 5.43\end{array}$ & $\begin{array}{l}77.88 \\
\pm 1.37\end{array}$ & $\begin{array}{l}39.49 \\
\pm 2.55\end{array}$ & $\begin{array}{c}5.29 \\
\pm 0.35\end{array}$ & $\begin{array}{c}2.13 \\
\pm 0.32\end{array}$ & 30.97 \\
\hline
\end{tabular}

The basic characteristics (FM and oDM) of the DSS sample used in series 1 and series 2 slightly differed from each other. This could be explained by different storage durations of the DSS at the treatment plant or seasonal variations. However, both DM and oDM contents were higher compared to Bertau et al. [75], in which a DM content of $2.40 \pm 0.50 \%$ FM and an oDM content of $49.00 \pm 2.00 \% \mathrm{DM}$ were reported. It cannot be expected that the characteristics of DSS fluctuate as strong as the characteristics OFMSW, but wastewater treatment plants can operate with different treatment approaches influencing DSS characteristics. The contents for $\mathrm{C}, \mathrm{H}$, and $\mathrm{N}$ of DSS (series 2) are almost identical, compared to mean values in Maier and Scheffknecht [76].

Based on Equation (1), the calculated stoichiometric biogas potential of the OFMSW was $990 \mathrm{~L} / \mathrm{kg}_{\mathrm{oDM}}\left(771 \mathrm{~L} / \mathrm{kg}_{\mathrm{DM}}, 257 \mathrm{~L} / \mathrm{kg}_{\mathrm{FM}}\right)$, with a stoichiometric $\mathrm{CH}_{4}$ potential of $506 \mathrm{~L} / \mathrm{kg}_{\mathrm{oDM}}\left(394 \mathrm{~L} / \mathrm{kg}_{\mathrm{DM}}, 131 \mathrm{~L} / \mathrm{kg}_{\mathrm{FM}}\right)$. The DSS of series 2 reached a stoichiometric biogas potential of $1051 \mathrm{~L} / \mathrm{kg}_{\mathrm{oDM}}\left(633 \mathrm{~L} / \mathrm{kg}_{\mathrm{DM}}, 26 \mathrm{~L} / \mathrm{kg}_{\mathrm{FM}}\right)$, leading to a stoichiometric $\mathrm{CH}_{4}$ potential of $514 \mathrm{~L} / \mathrm{kg}_{\mathrm{oDM}}\left(400 \mathrm{~L} / \mathrm{kg}_{\mathrm{DM}}, 16 \mathrm{~L} / \mathrm{kg}_{\mathrm{FM}}\right)$. In the literature, the calculated stoichiometric yields of DSS were between 919 and $1533 \mathrm{~L}_{\text {biogas }} / \mathrm{kg}_{\mathrm{oDM}}$ and between 462 and $772 \mathrm{~L}_{\mathrm{CH} 4} / \mathrm{kg}_{\mathrm{oDM}}$, while OFMSW reached $1087 \mathrm{~L}_{\text {biogas }} / \mathrm{kg}_{\mathrm{oDM}}$ and $596 \mathrm{~L}_{\mathrm{CH} 4} / \mathrm{kg}_{\mathrm{oDM}}$. These values are in line with the DSS and OFMSW samples used in this study $[1,75,76]$. However, stoichiometric biogas and $\mathrm{CH}_{4}$ yields assume complete digestion, which is not achieved in practice.

\subsection{Influence of Process Temperature on AD of OFMSW}

For both test series, the influence of process temperatures on AD of OFMSW together with DSS is depicted in Figures 1-3. Figure 1 presents the results for $\mathrm{SBG}_{\mathrm{OFMSW}}$ and DSS and $\mathrm{SMY}_{\mathrm{OFMSW}}$ and DSS in the different digester configurations. The ratio of oDM from OFMSW to oDM from DSS according to the specifications of VDI 4630 [66] was 0.30 in test series 1 and 0.32 in test series 2. From a digester perspective, the influence of the OFMSW on biogas and $\mathrm{CH}_{4}$ yields per digester ( $\mathrm{SBG}_{\mathrm{OFMSW}}$ and DSS and $\mathrm{SMY}_{\mathrm{OFMSW}}$ and DSS) was relatively low due to a larger share of inoculum (DSS), compared to OFMSW. Figure 2 presents the results for specific biogas yields (SBG) and methane yields (SMY) for OFMSW and DSS alone at the different process temperatures. In both test series, higher temperatures were beneficial for $\mathrm{SBG}_{\mathrm{DSS}}$ and $\mathrm{SM} Y_{\mathrm{DSS}}$. Based on the results for $\mathrm{SBG}_{\mathrm{DSS}}$ and $\mathrm{SMY}_{\mathrm{DSS}}$ it 
can be assumed that the residual $\mathrm{CH}_{4}$ potential of DSS in wastewater treatment plants could be better exploited through mesophilic temperatures in the storage tank serving as a second digester or by increasing the HRT for sewage sludge in the main AD unit.
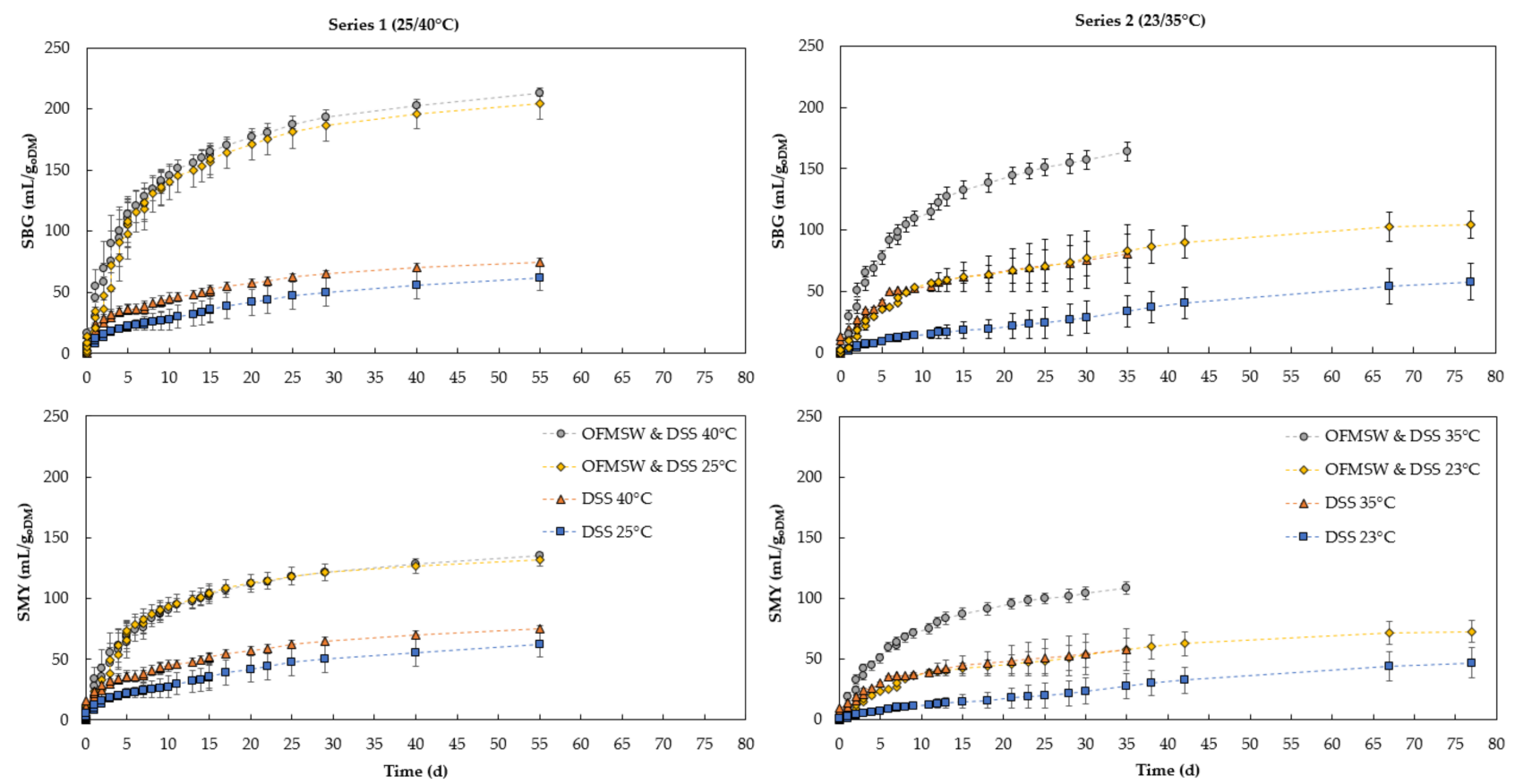

Figure 1. Specific biogas yield (SBG) and specific methane yield (SMY) for the mixture of the organic fraction of municipal solid waste (OFMSW) and digested sewage sludge (DSS); mean values \pm standard deviation ( $n=2$ for DSS, $n=4$ for OFMSW and DSS) based on organic dry matter (oDM), gas volume at $1013 \mathrm{hPa}, 0{ }^{\circ} \mathrm{C}$.

In test series 1, the variants using OFMSW as feedstock achieved similar SBG OFMSW and DSS and $\mathrm{SMY}_{\mathrm{OFMSW}}$ and DSs per digester (Figure 1). By subtracting the yields of the blank variants

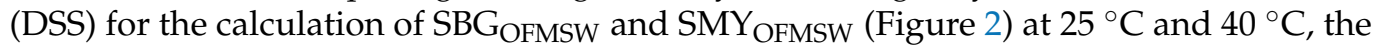
lower $\mathrm{SBG}_{\mathrm{DSS}}$ and $\mathrm{SMY} \mathrm{DSS}_{\mathrm{DS}}$ at $25^{\circ} \mathrm{C}$ led to slightly higher yields for OFMSW at $25^{\circ} \mathrm{C}$. In general, the two test series showed strong differences regarding the final SBG and SMY. While the $\mathrm{SBG}_{\text {OFMSW }}$ at $25^{\circ} \mathrm{C}$ (after $56 \mathrm{~d}$ ) was $623 \mathrm{~mL} / \mathrm{g}_{\mathrm{oDM}}$, the $\mathrm{SBG}$ OFMSw at $23{ }^{\circ} \mathrm{C}$ (after $77 \mathrm{~d}$ ) dropped by $57.7 \%$. The results for the $\mathrm{SBG}_{\mathrm{OFMSW}}$ and $\mathrm{SMY}_{\mathrm{OFMSW}}$ digested at 25 and $23{ }^{\circ} \mathrm{C}$ showed that an extended HRT in test series $2(21 \mathrm{~d})$ was not sufficient to deliver similar results. However, the results $\left(25^{\circ} \mathrm{C}\right.$ beneficial, $23^{\circ} \mathrm{C}$ disadvantageous $)$ should be questioned because all yields were lower in test series 2 , even for variants that were operated at $35^{\circ} \mathrm{C}$. Nevertheless, it can be deduced that the microorganisms do not perform efficiently without heating or strongly increased HRT, which was confirmed by King et al. [51]. As mentioned, the $\mathrm{SMY}_{\mathrm{OFMSW}}$ at $35^{\circ} \mathrm{C}$ also decreased by approximately $17.5 \%$, compared to OFMSW digested at $40{ }^{\circ} \mathrm{C}$, probably due to the lower activity of microorganisms [55]. Although both test series were executed with the same procedure, the differences between the OFMSW variants at $23,25,35$, and $40^{\circ} \mathrm{C}$ could also be influenced by variations in the quality of the DSS and the potential inhomogeneity of OFMSW samples.

All final SBG and SMY for DSS and OFMSW alone and corresponding $\mathrm{CH}_{4}$ concentrations are presented in Table 4 . The $\mathrm{CH}_{4}$ concentrations of OFMSW did not vary as strongly as the $\mathrm{CH}_{4}$ concentrations of the DSS at different temperatures. Between the SBG SMY ${ }_{\text {DSS }}$ at 25 and $40{ }^{\circ} \mathrm{C}$ and between the DSS at 23 and $35{ }^{\circ} \mathrm{C}$, a difference of almost $10 \%$-points with higher $\mathrm{CH}_{4}$ concentrations at lower temperatures was measured. Similar increases in $\mathrm{CH}_{4}$ concentrations through reduced process temperatures were discovered in the literature [32]. It can be concluded that the inoculum is the major and liquid component in the digester, and therefore, the biogas composition can be influenced toward higher $\mathrm{CH}_{4}$ concentrations through lowered temperatures. 

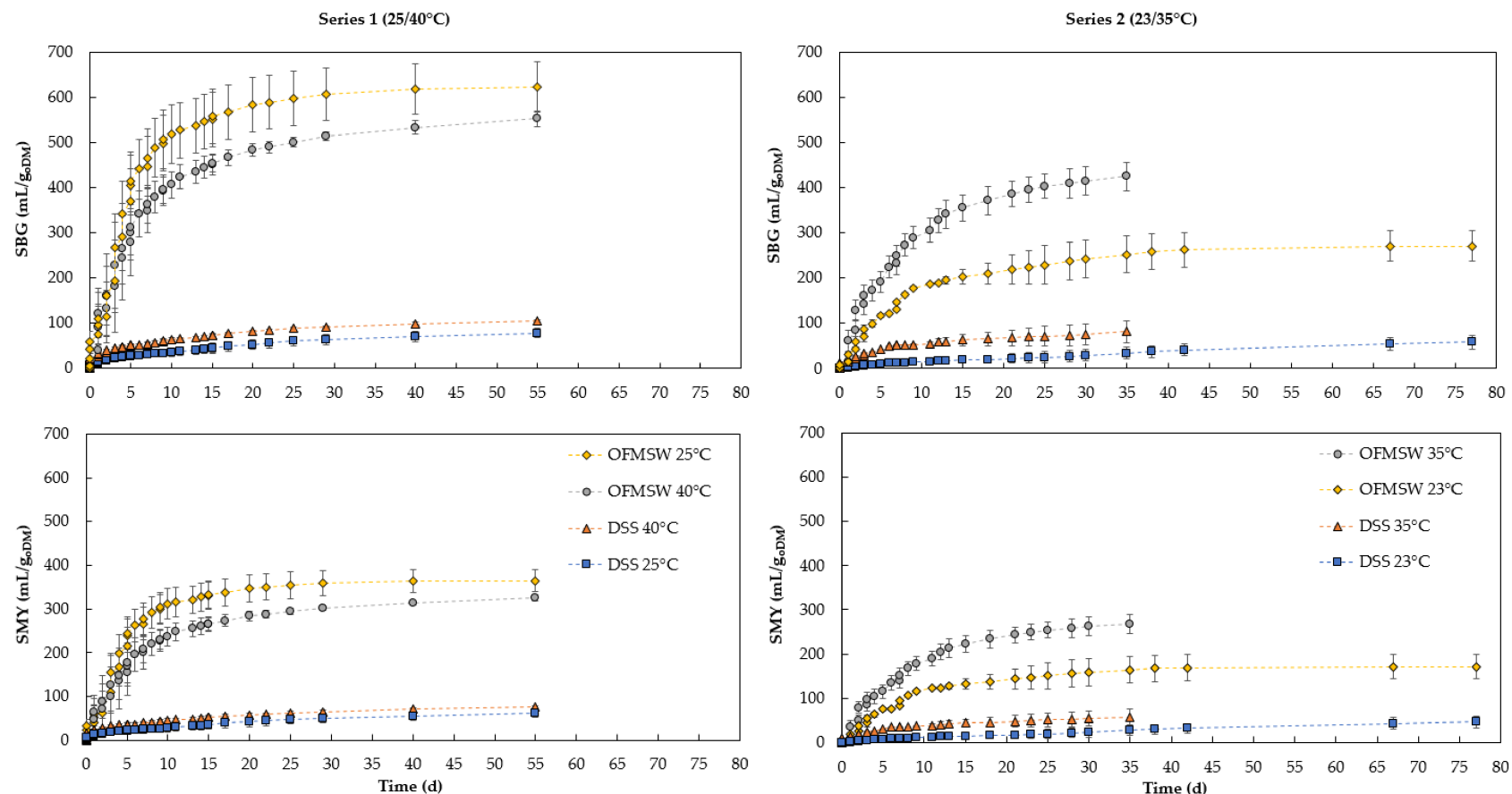

Figure 2. Specific biogas yield (SBG) and methane yield (SMY) for the organic fraction of municipal solid waste (OFMSW) alone and the digested sewage sludge (DSS) alone; mean values \pm standard deviation ( $n=2$ for DSS, $n=4$ for OFMSW) based on organic dry matter (oDM), gas volume at $1013 \mathrm{hPa}, 0^{\circ} \mathrm{C}$.
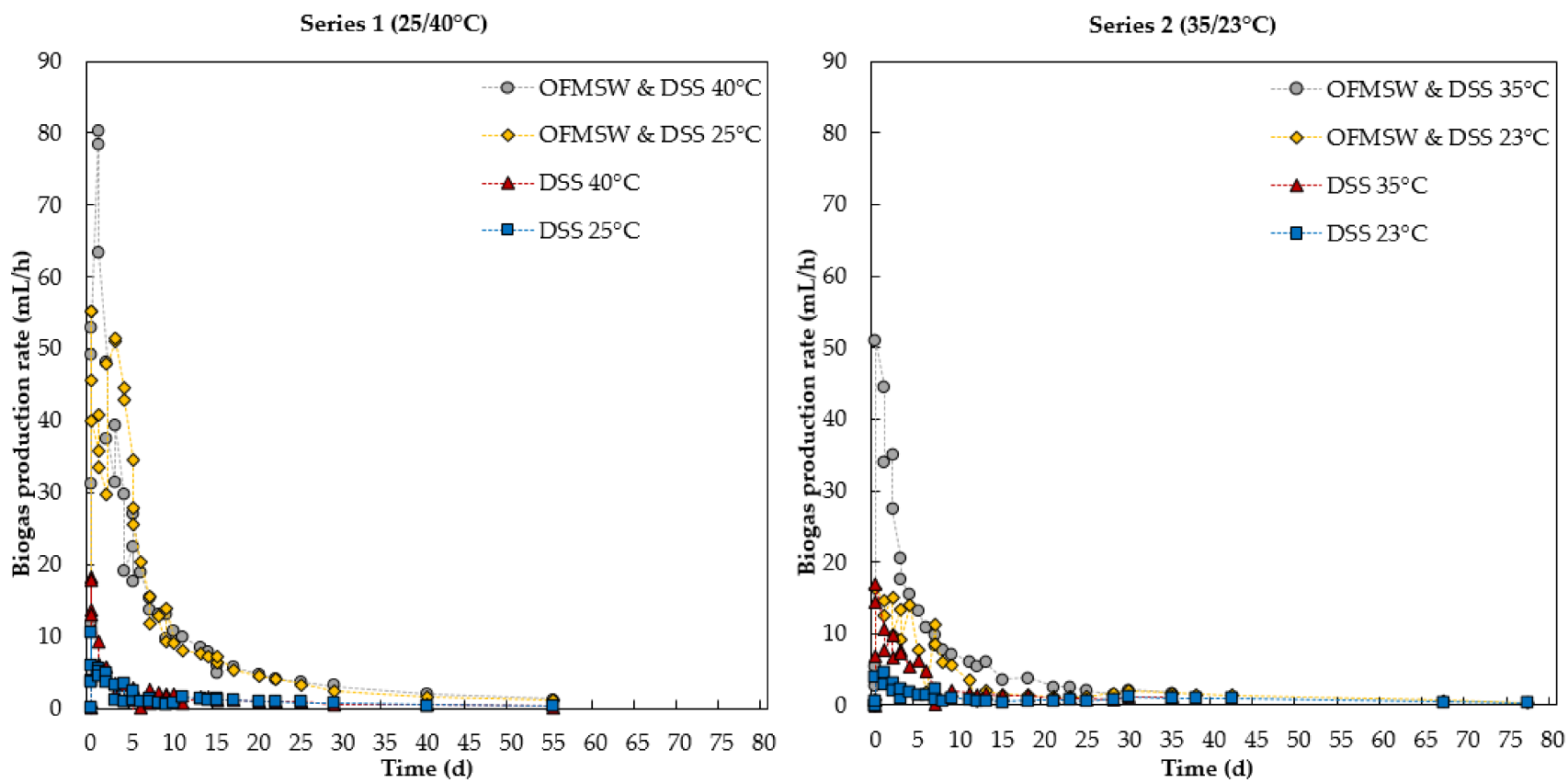

Figure 3. Biogas production rates for the mixtures of the organic fraction of municipal solid waste (OFMSW) and digested sewage sludge (DSS), and for DSS alone; mean values ( $\mathrm{n}=2$ for DSS, $\mathrm{n}=4$ for OFMSW and DSS), gas volume at $1013 \mathrm{hPa}, 0^{\circ} \mathrm{C}$.

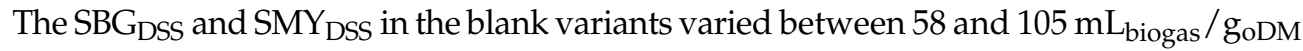
and between 47 and $75 \mathrm{~mL} \mathrm{CH}_{4} / \mathrm{g}_{\mathrm{oDM}}$, reaching the highest yields at $40{ }^{\circ} \mathrm{C}$, followed by 35 and $25^{\circ} \mathrm{C}$ at a similar level. Although reaching the highest $\mathrm{CH}_{4}$ concentrations, the DSS variant at $23{ }^{\circ} \mathrm{C}$ clearly delivered the worst results for SBG and SMY. The final experimental yields equaled approximately $6-10 \%$ (SBG) or $9-15 \%$ (SMY), compared to the theoretical stoichiometric yields for DSS in series 2 (Table 3). This can be explained by the 
circumstance that the DSS already was AD treated, and the remaining oDM suggests a low digestibility. However, both series showed that there is still energy potential within the DSS that could be exploited better. In Germany, the average SBG production from sewage sludge amounts to $520 \mathrm{~mL} / \mathrm{g}_{\mathrm{oDM}}$ [22]. The determined residual SBG potentials equaled approximately $10-20 \%$ of this average, showing that efficiency enhancements are possible. In addition, the results for SMY ${ }_{\text {DSS }}$ at $23{ }^{\circ} \mathrm{C}$ coincide with those of Liu et al. [39], in which the transition to the psychrophilic temperature range is accompanied by a doubled HRT to reach approximately similar $\mathrm{CH}_{4}$ yields.

Table 4. Specific biogas yields (SBG), methane yields (SMY), and $\mathrm{CH}_{4}$ concentrations $(\sigma)$ of the digested sewage sludge (DSS) and the organic fraction of municipal solid waste (OFMSW) at different temperatures and retention times; mean values \pm standard deviation.

\begin{tabular}{cccc}
\hline Variant & SBG $\left(\mathbf{m L} / \mathbf{g}_{\mathbf{o D M}}\right)$ & SMY $\left(\mathbf{m L} / \mathbf{g}_{\mathbf{o D M}}\right)$ & $\boldsymbol{\sigma} \mathbf{( \% )}$ \\
\hline DSS T40 $(56 \mathrm{~d})$ & $105.45 \pm 2.16$ & $74.75 \pm 2.92$ & $70.89 \pm 4.22$ \\
DSS T35 $(35 \mathrm{~d})$ & $80.75 \pm 23.92$ & $57.88 \pm 17.09$ & $71.69 \pm 0.07$ \\
DSS T25 $(56 \mathrm{~d})$ & $78.03 \pm 10.10$ & $62.06 \pm 10.38$ & $79.53 \pm 3.05$ \\
DSS T23 $(77 \mathrm{~d})$ & $57.67 \pm 14.86$ & $46.71 \pm 12.50$ & $80.99 \pm 0.86$ \\
\hline OFMSW T40 $(56 \mathrm{~d})$ & $552.80 \pm 17.22$ & $325.17 \pm 6.13$ & $58.82 \pm 0.84$ \\
OFMSW T35 (35 d) & $424.49 \pm 31.59$ & $268.35 \pm 26.74$ & $63.22 \pm 0.67$ \\
OFMSW T25 (56 d) & $623.91 \pm 56.22$ & $364.19 \pm 24.71$ & $58.37 \pm 1.41$ \\
OFMSW T23 (77 d) & $270.19 \pm 33.47$ & $171.89 \pm 21.19$ & $63.62 \pm 2.05$ \\
\hline
\end{tabular}

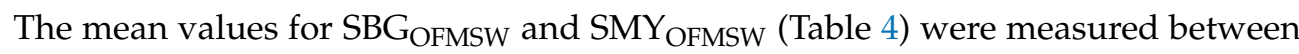
270 and $624 \mathrm{~mL}_{\text {biogas }} / \mathrm{g}_{\mathrm{oDM}}$ and was between 172 and $364 \mathrm{~mL}_{\mathrm{CH} 4} / \mathrm{g}_{\mathrm{oDM}}$, corresponding to approximately $27-63 \%$ (biogas) and $34-73 \%\left(\mathrm{CH}_{4}\right)$ of the stoichiometric yields. The variant at $25{ }^{\circ} \mathrm{C}$ delivered the best results but was indicated with the largest SD. As mentioned, this result can also be attributed to the calculation method presented in Equation (2) to Equation (6). When neglecting the two best performing digesters at $25{ }^{\circ} \mathrm{C}$ (SBG $\mathrm{OFMSW}$ of 700 and $650 \mathrm{~mL} / \mathrm{g}_{\mathrm{oDM}}$ ), the average SBGOFMSW drops to $570 \mathrm{~mL} / \mathrm{g}_{\mathrm{oDM}}$ equaling the SBG ${ }_{\text {OFMSW }}$ at $40{ }^{\circ} \mathrm{C}$. In total, an operating temperature of $25^{\circ} \mathrm{C}$ could be beneficial regarding the potential ratio between saved energy costs (heating) and $\mathrm{CH}_{4}$ yields at a probably similar level.

A study [51], in which an adaptation from mesophilic to psychrophilic AD temperatures took several months, could explain the results for the OFMSW variant at $23^{\circ} \mathrm{C}$. For the evaluation of $\mathrm{SBG}_{\mathrm{OFMSW}}$ and $\mathrm{SMY} \mathrm{OFMSW}_{\text {at }} 35^{\circ} \mathrm{C}$ (Table 4$)$, the reduced HRT (21 d) also has to be considered. Depending on the reactor design, typical OFMSW yields (SBG) in Germany vary between 80 and $120 \mathrm{~mL} / \mathrm{g}_{\mathrm{FM}}$ [58]. Normalized on oDM by using the DM and oDM contents of OFMSW (Table 3), SBG yields vary between 309 and $463 \mathrm{~mL} / \mathrm{g}_{\mathrm{oDM}}$. The determined gas potentials are similar considering the influence of laboratory conditions.

In addition, Figure 3 presents the biogas production rates for the digester configurations for both test series. The variants at higher temperatures showed higher production rates and thus higher methanogenic activity at the beginning of the experiment. This is also found in other studies [25,31,52]. In total, the peak values for the biogas production rates of the variants at 23 and $25^{\circ} \mathrm{C}$ were lower, but from approximately day 5 to day 10, the biogas production rates were higher or at a similar level, compared to the variants at 35 and $40{ }^{\circ} \mathrm{C}$. This could be attributed to a short adaption phase of the microorganisms as the diversity of microorganisms decreases with lowered temperatures $[53,54]$. For all variants, the biogas production occurred primarily in the first two weeks allowing conclusions for HRT in practice. The anaerobic treatment of DSS could be increased by one week in order to reduce the residual biogas potential of the DSS. For OFMSW, an HRT of 30 to 40 days seems appropriate in wet digestion with low shares of OFMSW in the mixture. In this study, an inoculum/substrate-ratio of approximately 0.3 in terms of oDM was applied. The HRT depends on various factors such as the organic loading rate or the digestion principle. Therefore, a recommendation of HRT of 30 to 40 days for OFMSW cannot be generalized. 
The comparison of process temperature-dependent SMY $\mathrm{DSS}_{\text {and }}$ SMY $\mathrm{YFMSW}_{\mathrm{O}}$ and $\mathrm{SMY}_{\text {DSS and OFMSW }}$ on day 35 of the experiments is presented in Figure 4 in order to determine correlations between process temperatures and $\mathrm{CH}_{4}$ yields for OFMSW and DSS. In the literature, different authors $[25,31,39,40,52]$ stated a linear correlation between $\mathrm{CH}_{4}$ yield and process temperature in $\mathrm{AD}$ for other substrates. As can be seen in Figure 4, the $\mathrm{SMY}_{\mathrm{DSS}}$ seemed to be linear dependent on the process temperature. The SMY $Y_{\mathrm{OFMSW}}$ and the $\mathrm{SMY}_{\mathrm{OFMSW}}$ and DSS delivered different results. While the exclusion of the results for $\mathrm{AD}$ of OFMSW at $25^{\circ} \mathrm{C}$ led to a relatively well-fitting linear trend, the joint reflection did not deliver a linear trend. However, the co-digestion of OFMSW with its various ingredients [1], together with DSS as inoculum delivering a variety of microorganisms [66], is not yet tested extensively. When assuming a linear correlation, lower $\mathrm{CH}_{4}$ yields through lower process temperatures could have been overcompensated by other process parameters in the AD of OFMSW and DSS at $25^{\circ} \mathrm{C}$. Nevertheless, it cannot be excluded that the process temperature at approximately $25^{\circ} \mathrm{C}$ provides favorable overall conditions. In additional research, this should be validated by detailed process monitoring and through repetition of the experiment.

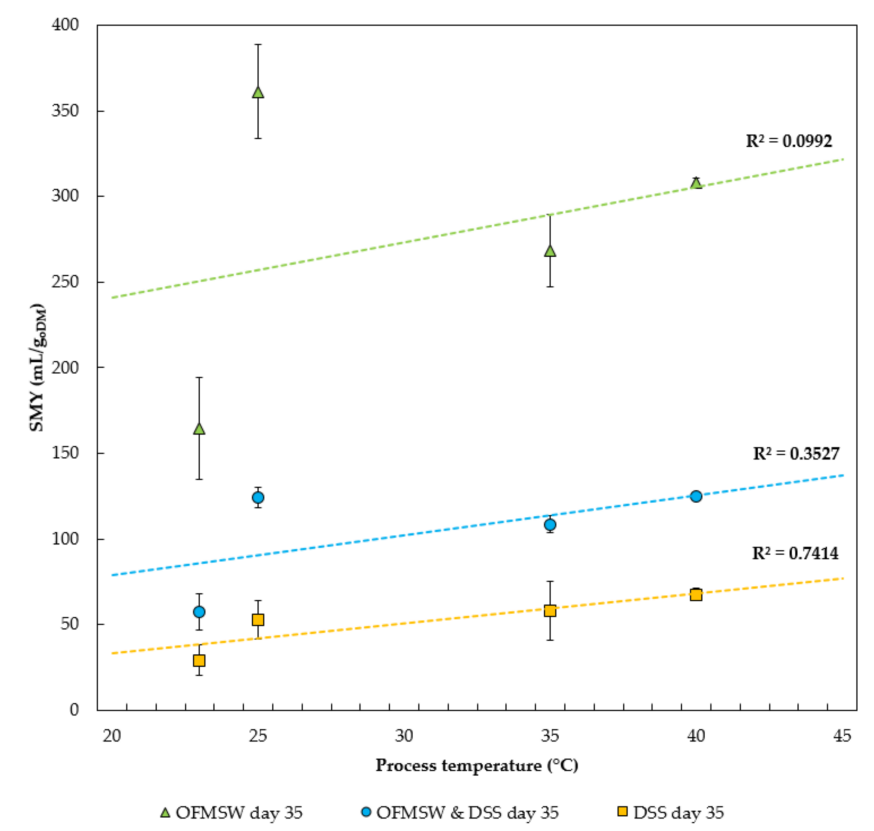

Figure 4. Specific methane yield (SMY) on day 35 of the experiment based on organic dry matter (oDM) for the organic fraction of municipal solid waste (OFMSW) and digested sewage sludge (DSS) alone and in the mixture. Gas volume at $1013 \mathrm{hPa}, 0^{\circ} \mathrm{C}$; mean values \pm standard deviation including trend lines with $\mathrm{n}=2$ for DSS, $\mathrm{n}=4$ for OFMSW, $\mathrm{n}=4$ for OFMSW and DSS.

\subsection{Efficiency Potentials through Lowered Process Temperatures}

By reducing operating temperatures, the efforts and costs for digester heating and technical equipment can be reduced or (depending on the ambient temperature) even completely eliminated. In general, the heat demand of biogas plants arises due to heat losses of the digester and because of the necessity to heat the incoming substrate (Appendix A). The main proportion of the heat demand is related to substrate heating. Therefore, it is advisable to preheat the amount of OFMSW before starting the AD process. In practice, this can be conducted by self-heating processes with a short phase of aerobic treatment, which is stopped as soon as the OFMSW reaches the designated process temperature for AD. However, this process leads to lower energy potentials of the OFMSW. Saved heating costs could possibly compensate for lower gas yields, especially if, as can be seen, for example, with DSS, the $\mathrm{CH}_{4}$ concentration increases due to the lower operating temperatures. The reduction of treatment costs for biogas purification is a possible secondary effect of lower operating temperatures. However, larger digester volumes with increased HRT, and sepa- 
rate sanitation systems (biowaste) seem to become necessary. The balance between energy savings due to lower digester temperatures, changes in biogas yields, and infrastructural costs has to be investigated in further research based on detailed simulation to determine optimum conditions due to various interdependencies.

In this study, an operating temperature of $25^{\circ} \mathrm{C}$ for the AD of OFMSW together with DSS delivered similar results, compared to an AD temperature of $40^{\circ} \mathrm{C}$, and could be beneficial. Although the experiments for AD of OFMSW were conducted in quadruplicate with relatively low $\mathrm{SD}$, the results have to be verified in further experiments at $25{ }^{\circ} \mathrm{C}$, especially due to the nonlinear correlation (Figure 4) and the findings of other authors $[25,31,52]$ that suggest a linear correlation between SMY and process temperatures. Moreover, the exclusion of the $25^{\circ} \mathrm{C}$ variants delivered well-fitting linear trends.

The estimation of an OFMSW-based AD plant with an annual throughput of 10,000 tons of OFMSW (Appendix A) can provide a basic understanding of the influence of the process temperature. When assuming the same energy yield provision at $25^{\circ} \mathrm{C}$, compared to the energy yield at $40^{\circ} \mathrm{C}$, the annual heat demand of the AD plant decreases by approximately $10 \%$. However, the hypothesis of heightened efficiencies in the AD of OFMSW together with DSS through lowered operating temperatures cannot be answered conclusively. If an operating temperature of $25^{\circ} \mathrm{C}$ proves in further research that it can deliver similar energy yields, an efficiency increase could be realistic. Otherwise, efficiency potentials through lowered operating temperatures have to be determined based on detailed models with a cost-oriented optimization approach.

Notwithstanding the above, the co-digestion of OFMSW together with DSS could also lead to further synergies. First, the SBG continued treatment in AD. Second, the DSS could serve as a suitable inoculum delivering a broad variety of microorganisms for the AD of OFMSW with its changing characteristics. Furthermore, the co-digestion of OFMSW, which has a high DM content, together with DSS, which has a low DM content, could be a beneficial option to achieve suitable DM contents for wet digestion systems such as stirred-tank reactors without adding water. The extension of existing wastewater treatment plants with AD units for co-digestion of OFMSW and DSS could be an approach worth investigating.

With or without prior AD, OFMSW typically provides compost products, mainly for application in agriculture. A major challenge in the utilization of OFMSW remains the removal of impurities, which was conducted manually in this study. Especially, effective removal of plastics is challenging, but a separated plastic fraction could be utilized in alternative treatment plants, e.g., for the production of fuels via pyrolysis $[77,78]$.

DSS is also used in agriculture, but its utilization as fertilizer is declining or even forbidden due to problematic ingredients such as heavy metals. Incineration plants currently utilize the major portion of the DSS. Therefore, the utilization possibilities or treatment options for digestates consisting of a mixture of OFMSW and DSS is a field of further research. Creating larger amounts of potentially problematic wastes with limited application possibilities should be avoided. The potentials for decreasing operating temperatures in AD are limited due to a decreasing diversity of microorganisms, as described by McAteer et al. [55]. The reduction of process temperatures could be an approach to improve the profitability of AD plants. This could also be relevant for energy crops-based AD plants. However, in a real-life and continuous AD, a constant temperature is also necessary. The temperature fluctuations should be lower for reactors at thermophilic temperature $\left( \pm 1^{\circ} \mathrm{C}\right)$ than in $\mathrm{AD}$ at mesophilic conditions $\left( \pm 3^{\circ} \mathrm{C}\right)$. A comparison of a heated German biogas plant and an unheated American biogas plant can be found in Lansing et al. [79].

\section{Conclusions}

The co-digestion of OFMSW together with DSS could create synergy effects such as achieving required DM contents necessary for the operation of wet digestion systems. In addition to its role as inoculum, the inherent $\mathrm{CH}_{4}$ potential of the DSS would be better exploited. In Germany and worldwide, the mesophilic process temperatures are most 
commonly used. Therefore, lowered process temperatures could positively influence biogas plants worldwide through reduced operating costs. The results were achieved with OFMSW and DSS but could also be relevant for AD of energy crops together with manure. However, lowered process temperatures could be problematic for biogas plants using substrates that need hygienic treatment such as OFMSW. A separate sanitation unit could become necessary leading to investment and operating costs. According to the German Biowaste Ordinance, only the treatment of OFMSW in AD at thermophilic temperatures fulfills the hygienic requirements, which is why biogas plants operated at mesophilic conditions are already equipped with a separate sanitation unit. From a legal perspective, lowered process temperatures are mainly relevant for biogas plants with separate sanitation units (e.g., mesophilic biogas plants using OFMSW) and for biogas plants operating at mesophilic temperatures without using critical feedstock such as energy-crop-based biogas plants.

Further experiments with thermophilic temperature levels, other AD substrates, and different AD systems should be carried out in order to validate the results of this study. In addition, detailed modeling and simulation of different biogas plants and their operation at lowered temperatures should be conducted, focusing on heat balance, energy output, and $\mathrm{AD}$ process parameters such as HRT, organic loading rate, or digester volumes.

Author Contributions: Conceptualization, G.S. and S.P.; methodology, G.S., J.P., H.O., and J.E.; validation, G.S., M.S., J.E., J.P., and J.M.; formal analysis, G.S.; investigation, G.S., M.S., and J.E.; writing—original draft preparation, G.S.; writing—review and editing, G.S. and J.M.; visualization, G.S. and J.M.; supervision, S.P., H.O., and J.M.; project administration, S.P.; funding acquisition, S.P. All authors have read and agreed to the published version of the manuscript.

Funding: This research was funded by the project ENsource, which was supported by the Ministry of Science, Research, and the Arts of the State of Baden-Wuerttemberg (Germany), and the European Regional Development Fund (ERDF 2014-2020). Support code: FEIH_ZAFH_562822, FEIH_ZAFH_1248932.

Institutional Review Board Statement: Not applicable.

Informed Consent Statement: Not applicable.

Data Availability Statement: The data presented in this study are available on request from the corresponding author.

Acknowledgments: The authors would like to thank Sabine Nugent for language editing.

Conflicts of Interest: The authors declare no conflict of interest. The funders had no role in the design of the study; in the collection, analyses, or interpretation of data; in the writing of the manuscript, or in the decision to publish the results.

$\begin{array}{ll}\text { Abbreviations } \\ \text { AD } & \text { anaerobic digestion } \\ \text { DM } & \text { dry matter } \\ \text { DSS } & \text { digested sewage sludge } \\ \text { FM } & \text { fresh mass } \\ \text { GHG } & \text { greenhouse gas(es) } \\ \text { HRT } & \text { hydraulic retention time } \\ \text { oDM } & \text { organic dry matter } \\ \text { MSW } & \text { municipal solid waste } \\ \text { OFMSW } & \text { organic fraction of municipal solid waste } \\ \text { SBG } & \text { specific biogas yield } \\ \text { SD } & \text { standard deviation } \\ \text { SMY } & \text { specific methane yield }\end{array}$

\section{Appendix A}

For the estimation of efficiency potentials through lowered operating temperatures, heat demands for OFMSW-based AD plants can be estimated based on the heat demand for 
substrate heating and based on heat losses of the digester. The heat quantity for substrate heating was calculated as

$$
Q_{\text {substrate }}=c_{\text {water }} \cdot m_{\text {water }} \cdot \Delta T \text {, }
$$

where $Q_{\text {substrate }}(\mathrm{J})$ is the thermal energy for substrate heating, $c_{\text {water }}(\mathrm{J} / \mathrm{kg} \mathrm{K})$ is the specific heat capacity of substrate, $m_{\text {water }}(\mathrm{kg})$ is the mass of substrate, and $\Delta \mathrm{T}(\mathrm{K})$ is the temperature difference between substrate and ambient temperature. Since the specific heat capacity of the substrate was not known, the value for water was used.

The heat flow or the heat loss capacity of the digester was calculated as

$$
\dot{Q}_{\text {total }}=\sum U_{\text {component }} \cdot A_{\text {component }} \cdot \Delta T \text {, }
$$

where $\dot{Q}_{\text {total }}(\mathrm{W})$ is the sum of the heat flow for all digester components, $U_{\text {component }}\left(\mathrm{W} / \mathrm{m}^{2}\right.$ $\mathrm{K})$ is the heat transition coefficient for each digester component, and $A_{\text {component }}\left(\mathrm{m}^{2}\right)$ is the surface area of each component.

For the OFMSW-based AD plant characteristics, an annual throughput of 10,000 tons of OFMSW treated in a digester with a total surface area of $814 \mathrm{~m}^{2}$ with an overall heat transition coefficient of $0.35 \mathrm{~W} / \mathrm{m}^{2} \mathrm{~K}$ was chosen. For OFMSW, a density equal to water was assumed together with the assumption that it would take $1.16 \mathrm{kWh}$ per ton of OFMSW to heighten the temperature by $1 \mathrm{~K}$. In addition, an average ambient temperature of $10^{\circ} \mathrm{C}$ was assumed. The combined heat and power unit was defined with a thermal efficiency of 0.45 and a biogas yield of $80 \mathrm{~mL} / \mathrm{g}_{\mathrm{FM}}[58]$.

\section{References}

1. Campuzano, R.; González-Martínez, S. Characteristics of the organic fraction of municipal solid waste and methane production: A review. Waste Manag. 2016, 54, 3-12. [CrossRef] [PubMed]

2. Vea, E.B.; Romeo, D.; Thomsen, M. Biowaste valorisation in a future circular bioeconomy. Procedia CIRP 2018, 69, 591-596. [CrossRef]

3. CD. 1999/31/EC. Council Directive on the Landfill of Waste. Available online: https:/ / eur-lex.europa.eu/legal-content/EN/TXT/ $\mathrm{PDF}$ / ?uri=CELEX:31999L0031\&from=DE (accessed on 26 January 2021).

4. D. 2008/98/EC. Directive 2008/98/EC of the European Parliament and of the Council on waste and repealing certain Directives. Available online: https:/ / eur-lex.europa.eu/legal-content/EN/TXT/PDF/?uri=CELEX:32008L0098\&from=EN (accessed on 26 January 2021).

5. D. 2018/850. Directive (EU) 2018/850 of the European Parliament and of the Council amending Directive 1999/31/EC on the Landfill of Waste. Available online: https:/ / eur-lex.europa.eu/legal-content/EN/TXT/PDF/?uri=CELEX:32018L0850\&from=EN (accessed on 26 January 2021).

6. Lin, L.; Xu, F.; Ge, X.; Li, Y. Improving the sustainability of organic waste management practices in the food-energy-water nexus: A comparative review of anaerobic digestion and composting. Renew. Sustain. Energy Rev. 2018, 89, 151-167. [CrossRef]

7. Hungría, J.; Gutiérrez, M.C.; Siles, J.A.; Martín, M.A. Advantages and drawbacks of OFMSW and winery waste co-composting at pilot scale. J. Clean. Prod. 2017, 164, 1050-1057. [CrossRef]

8. Mata-Alvarez, J.; Macé, S.; Llabrés, P. Anaerobic digestion of organic solid wastes. An overview of research achievements and perspectives. Bioresour. Technol. 2000, 74, 3-16. [CrossRef]

9. Rocamora, I.; Wagland, S.T.; Villa, R.; Simpson, E.W.; Fernández, O.; Bajón-Fernández, Y. Dry anaerobic digestion of organic waste: A review of operational parameters and their impact on process performance. Bioresour. Technol. 2020, 299, 122681. [CrossRef]

10. Reichard, T. Biogasanlagen in der Steiermark: Eine Bestandsaufnahme im Juli 2005; 2006. Available online: https: //www.abfallwirtschaft.steiermark.at/cms/dokumente/10212870_46555/a8aebd7f/Gesamtwerk_Biogasanlage_in_der_ Steiermark_Internetversion.pdf (accessed on 11 May 2020).

11. Sankoh, F.P.; Yan, X.; Tran, Q. Environmental and health impact of solid waste disposal in developing cities: A case study of Granville Brook Dumpsite, Freetown, Sierra Leone. JEP 2013, 4, 665-670. [CrossRef]

12. Malinauskaite, J.; Jouhara, H.; Czajczyńska, D.; Stanchev, P.; Katsou, E.; Rostkowski, P.; Thorne, R.J.; Colón, J.; Ponsá, S.; Al-Mansour, F.; et al. Municipal solid waste management and waste-to-energy in the context of a circular economy and energy recycling in Europe. Energy 2017, 141, 2013-2044. [CrossRef]

13. Awiszus, S.; Meissner, K.; Reyer, S.; Müller, J. Gärrestverwertung in Einer Warmlufttrocknungsanlage mit Integrierter Stickstoffrückgewinnung; Landtechnik: Darmstadt, Germany, 2018. [CrossRef]

14. United Nations General Assembly. The Future We Want. Available online: https://www.un.org/en/development/desa/ population/migration/generalassembly/docs/globalcompact/A_RES_66_288.pdf (accessed on 11 May 2020). 
15. Jain, S.; Newman, D.; Nzihou, A.; Dekker, H.; Le Feuvre, P.; Richter, H.; Gobe, F.; Morton, C.; Thompson, R. Global Potential of Biogas; 2019. Available online: https://www.worldbiogasassociation.org/wp-content/uploads/2019/09/WBA-globalreport56ppa4_digital-Sept-2019.pdf (accessed on 4 March 2021).

16. Hussein, A.I.; Mansour, M.S.M. Solid waste issue: Sources, composition, disposal, recycling, and valorization. Egypt. J. Pet. 2018, 27, 1275-1290. [CrossRef]

17. Saini, R.; Osorio-Gonzalez, C.S.; Hegde, K.; Brar, S.K.; Magdouli, S.; Vezina, P.; Avalos-Ramirez, A. Lignocellulosic biomass-based biorefinery: An insight into commercialization and economic standout. Curr. Sustain. Renew. Energy Rep. 2020, 7, 122-136. [CrossRef]

18. Sara, M.; Rouissi, T.; Brar, S.K.; Blais, J.F. Life Cycle Analysis of Potential Substrates of Sustainable Biorefinery. In Platform Chemical Biorefinery; Elsevier: Amsterdam, The Netherlands, 2016; pp. 55-76. ISBN 9780128029800.

19. Wilken, D.; Bontempo, G.; Fürst, M.; Hofmann, F.; Strippel, F.; Kramer, A.; Ricci-Jürgensen, M. Biowaste to Biogas. Available online: https:/ / www.biogas.org/edcom/webfvb.nsf/id/DE-biowaste-to-biogas_eng/\$file/biowaste-to-biogas.pdf (accessed on 3 March 2021).

20. Fritsche, W.; Laplace, F. Mikrobiologie; Spektrum Akad. Verl.: Berlin/Heidelberg, Germany, 2002; ISBN 3827411076.

21. Munk, K.; Dersch, P.; Eikmanns, B.; Eikmanns, M.; Fischer, R.; Jahn, D.; Jahn, M.; Nethe-Jaenchen, R.; Requena, N.; Schultzem, B. Mikrobiologie: Taschenlehrbuch Biologie; Thieme: Stuttgart, Germany, 2008; ISBN 978-3-13-144861-3.

22. Energie aus Biomasse: Grundlagen, Techniken und Verfahren; Kaltschmitt, M.; Hartmann, H.; Hofbauer, H. (Eds.) Springer Vieweg: Berlin/Heidelberg, Germany, 2016; ISBN 9783662474389.

23. Kämpfer, P.; Weißenfels, W.D. Biologische Behandlung Organischer Abfälle, 1st ed.; Springer: Berlin/Heidelberg, Germany, 2012; ISBN 3642626238.

24. Mähnert, P. Kinetik der Biogasproduktion aus Nachwachsenden Rohstoffen und Gülle. 2007. Available online: https:/ / edoc.huberlin.de/bitstream/handle/18452/16303/maehnert.pdf?sequence=1\&isAllowed=y (accessed on 5 March 2021).

25. Westerholm, M.; Isaksson, S.; Sun, L.; Schnürer, A. Microbial community ability to adapt to altered temperature conditions influences operating stability in anaerobic digestion. Energy Procedia 2017, 105, 895-900. [CrossRef]

26. Jain, S.; Wolf, I.T.; Lee, J.; Tong, Y.W. A comprehensive review on operating parameters and different pretreatment methodologies for anaerobic digestion of municipal solid waste. Renew. Sustain. Energy Rev. 2015, 52, 142-154. [CrossRef]

27. Vindis, P.; Mursec, B.; Janzekovic, M.; Cus, F. The impact of mesophilic and thermophilic anaerobic digestion on biogas production. J. Achiev. Mater. Manuf. Eng. 2009, 36, 192-198.

28. BMJV. Verordnung über die Verwertung von Bioabfällen auf landwirtschaftlich, forstwirtschaftlich und gärtnerisch genutzten Böden (Bioabfallverordnung): BioAbfV. Available online: https://www.gesetze-im-internet.de/bioabfv/BioAbfV.pdf (accessed on 29 January 2021).

29. Zábranská, J.; Štěpová, J.; Wachtl, R.; Jeníček, P.; Dohányos, M. The activity of anaerobic biomass in thermophilic and mesophilic digesters at different loading rates. Water Sci. Technol. 2000, 42, 49-56. [CrossRef]

30. Ahring, B.K.; Ibrahim, A.A.; Mladenovska, Z. Effect of temperature increase from 55 to $65{ }^{\circ} \mathrm{C}$ on performance and microbial population dynamics of an anaerobic reactor treating cattle manure. Water Res. 2001, 35, 2446-2452. [CrossRef]

31. Kashyap, D.R.; Dadhich, K.S.; Sharma, S.K. Biomethanation under psychrophilic conditions: A review. Bioresour. Technol. 2003, 87, 147-153. [CrossRef]

32. Connaughton, S.; Collins, G.; O'Flaherty, V. Psychrophilic and mesophilic anaerobic digestion of brewery effluent: A comparative study. Water Res. 2006, 40, 2503-2510. [CrossRef] [PubMed]

33. LfU. Biogashandbuch Bayern. Available online: https://www.lfu.bayern.de/energie/biogashandbuch/index.htm (accessed on 11 May 2020).

34. Effenberger, M.; Kaiser, F.; Metzner, T.; Gronauer, A. Sicherung der Prozessstabilität in Landwirtschaftlichen Biogasanlagen; Information Bayerische Landesanstalt für Landwirtschaft: Freising-Weihenstephan, Germany, 2008.

35. Amon, T.; Behrendt, U.P.; Daniel-Gromke, J. Leitfaden Biogas: Von der Gewinnung zur Nutzung; FNR: Gülzow, Germany, 2013; ISBN 3-00-014333-5.

36. Donoso-Bravo, A.; Bandara, W.M.K.R.T.W.; Satoh, H.; Ruiz-Filippi, G. Explicit temperature-based model for anaerobic digestion: Application in domestic wastewater treatment in a UASB reactor. Bioresour. Technol. 2013, 133, 437-442. [CrossRef]

37. Fernández-Rodríguez, J.; Pérez, M.; Romero, L.I. Comparison of mesophilic and thermophilic dry anaerobic digestion of OFMSW: Kinetic analysis. Chem. Eng. J. 2013, 232, 59-64. [CrossRef]

38. Szyłak-Szydłowski, M.; Kulig, A.; Miaśkiewicz-Pęska, E. Seasonal changes in the concentrations of airborne bacteria emitted from a large wastewater treatment plant. Int. Biodeterior. Biodegrad. 2016, 115, 11-16. [CrossRef]

39. Liu, D.; Zhang, L.; Chen, S.; Buisman, C.; Ter, H.A. Bioelectrochemical enhancement of methane production in low temperature anaerobic digestion at $10^{\circ} \mathrm{C}$. Water Res. 2016, 99, 281-287. [CrossRef]

40. Chala, B.; Oechsner, H.; Müller, J. Introducing temperature as variable parameter into kinetic models for anaerobic fermentation of coffee husk, pulp and mucilage. Appl. Sci. 2019, 9, 412. [CrossRef]

41. Kumar, A.; Samadder, S.R. Performance evaluation of anaerobic digestion technology for energy recovery from organic fraction of municipal solid waste: A review. Energy 2020, 197, 117253. [CrossRef] 
42. Jaimes-Estévez, J.; Zafra, G.; Martí-Herrero, J.; Pelaz, G.; Morán, A.; Puentes, A.; Gomez, C.; Castro, L.d.P.; Escalante Hernández, H. Psychrophilic Full scale tubular digester operating over eight years: Complete performance evaluation and microbiological population. Energies 2021, 14, 151. [CrossRef]

43. Lanko, I.; Flores, L.; Garfí, M.; Todt, V.; Posada, J.A.; Jenicek, P.; Ferrer, I. Life cycle assessment of the mesophilic, thermophilic, and temperature-phased anaerobic digestion of sewage sludge. Water 2020, 12, 3140. [CrossRef]

44. Pasalari, H.; Gholami, M.; Rezaee, A.; Esrafili, A.; Farzadkia, M. Perspectives on microbial community in anaerobic digestion with emphasis on environmental parameters: A systematic review. Chemosphere 2021, 270, 128618. [CrossRef]

45. Cavinato, C.; Bolzonella, D.; Pavan, P.; Fatone, F.; Cecchi, F. Mesophilic and thermophilic anaerobic co-digestion of waste activated sludge and source sorted biowaste in pilot- and full-scale reactors. Renew. Energy 2013, 55, 260-265. [CrossRef]

46. Derbal, K.; Bencheikh-Lehocine, M.; Meniai, A.H. Study of biodegradability of organic fraction of municipal solids waste. Energy Procedia 2012, 19, 239-248. [CrossRef]

47. Moya, D.; Aldás, C.; López, G.; Kaparaju, P. Municipal solid waste as a valuable renewable energy resource: A worldwide opportunity of energy recovery by using waste-to-energy technologies. Energy Procedia 2017, 134, 286-295. [CrossRef]

48. Rajagopal, R.; Bellavance, D.; Rahaman, M.S. Psychrophilic anaerobic digestion of semi-dry mixed municipal food waste: For North American context. Process Saf. Environ. Protect. 2017, 105, 101-108. [CrossRef]

49. Lettinga, G. Challenge of psychrophilic anaerobic wastewater treatment. Trends Biotechnol. 2001, 19, 363-370. [CrossRef]

50. Saady, N.M.C.; Massé, D.I. Starting-up low temperature dry anaerobic digestion of cow feces and wheat straw. Renew. Energy 2016, 88, 439-444. [CrossRef]

51. King, S.M.; Barrington, S.; Guiot, S.R. In-storage psychrophilic anaerobic digestion of swine manure: Acclimation of the microbial community. Biomass Bioenergy 2011, 35, 3719-3726. [CrossRef]

52. Hussain, A.; Dubey, S.K. Specific methanogenic activity test for anaerobic degradation of influents. Appl. Water Sci. 2017, 7, 535-542. [CrossRef]

53. Watanabe, K.; Koyama, M.; Ueda, J.; Ban, S.; Kurosawa, N.; Toda, T. Effect of operating temperature on anaerobic digestion of the Brazilian waterweed Egeria densa and its microbial community. Anaerobe 2017, 47, 8-17. [CrossRef]

54. Gaby, J.C.; Zamanzadeh, M.; Horn, S.J. The effect of temperature and retention time on methane production and microbial community composition in staged anaerobic digesters fed with food waste. Biotechnol. Biofuels 2017, 10, 302. [CrossRef] [PubMed]

55. McAteer, P.G.; Christine Trego, A.; Thorn, C.; Mahony, T.; Abram, F.; O'Flaherty, V. Reactor configuration influences microbial community structure during high-rate, low-temperature anaerobic treatment of dairy wastewater. Bioresour. Technol. 2020, 307, 123221. [CrossRef]

56. Luning, L.; van Zundert, E.H.M.; Brinkmann, A.J.F. Comparison of dry and wet digestion for solid waste. Water Sci. Technol. 2003, 48, 15-20. [CrossRef] [PubMed]

57. Rajagopal, R.; Ghosh, D.; Ashraf, S.; Goyette, B.; Zhao, X. Effects of low-temperature dry anaerobic digestion on methane production and pathogen reduction in dairy cow manure. Int. J. Environ. Sci. Technol. 2019, 16, 4803-4810. [CrossRef]

58. Kern, M.; Raussen, T. Biogas-Atlas; 1. Aufl.; Witzenhausen-Institut für Abfall, Umwelt und Energie GmbH: Witzenhausen, Germany, 2014; ISBN 392867367X.

59. Thien, T.; Cu, T.; Cuong, P.H.; Le, H.T.; van Chao, N.; Le Anh, X.; Trach, N.X.; Sommer, S.G. Manure management practices on biogas and non-biogas pig farms in developing countries-using livestock farms in Vietnam as an example. J. Clean. Prod. 2012, 27, 64-71. [CrossRef]

60. Daniel-Gromke, J. Anlagenbestand Biogas und Biomethan-Biogaserzeugung und-nutzung in Deutschland: (FKZ 37EV 161110 ); DBFZ Deutsches Biomasseforschungszentrum Gemeinnützige GmbH: Leipzig, Germany, 2017; ISBN 978-3-946629-24-5.

61. Fachverband Biogas. Branchenzahlen 2018 und Prognose der Branchenentwicklung 2019. 2019. Available online: https://www.biogas. org/edcom/webfvb.nsf/id/de_branchenzahlen (accessed on 11 May 2020).

62. Völler, K. Branchenbarometer Biomethan 2020. Available online: https://www.dena.de/fileadmin/dena/Publikationen/PDFs/ 2020/Brachenbarometer_Biomethan_2020.pdf (accessed on 26 January 2021).

63. Guss, H.; Pertagnol, J.; Hauser, E.; Wern, B.; Baur, F.; Gärtner, S.; Rettenmaier, N.; Reinhardt, G. Biogas-Quo Vadis? Saarbrücken: Heidelberg, Germany, 2016; Available online: https://www.ifeu.de/fileadmin/uploads/landwirtschaft/pdf/Biogas_quo_vadis_ final_report_2016.pdf (accessed on 27 February 2021).

64. Scheftelowitz, M.; Rensberg, N.; Denysenko, V.; Daniel-Gromke, J.; Stinner, W.; Hillebrand, K.; Naumann, K.; Peetz, D.; Hennig, C.; Thrän, D.; et al. Stromerzeugung aus Biomasse-Vorhaben IIa Biomasse: Zwischenbericht Mai 2015; Leipzig. 2015. Available online: https:/ / www.dbfz.de/fileadmin/eeg_monitoring/berichte/01_Monitoring_ZB_Mai_2015.pdf (accessed on 27 February 2021).

65. Barchmann, T.; Pohl, M.; Denysenko, V.; Fischer, E.; Hofmann, J.; Lenhart, M.; Postel, J.; Liebetrau, J.; Effenberger, M.; Kissel, R.; et al. Biogas-Messprogramm III, Gülzow. 2021. Available online: https:/ /biogas.fnr.de/biogasmessprogramm-iii/ (accessed on 27 February 2021).

66. VDI 4630. Fermentation of Organic Materials: Characterisation of the Substrate, Sampling, Collection of Material Data, Fermentation Tests; Verein Deutscher Ingenieure e.V.: Düsseldorf, Germany, Sweden, 2016.

67. DIN EN 12579. Bodenverbesserungsmittel und Kultursubstrate-Probenahme 65.080; Beuth Verlag: Berlin, Germany, 2014.

68. DIN EN 13040. Bodenverbesserungsmittel und Kultursubstrate-Probenherstellung für Chemische und Physikalische Untersuchungen, Bestimmung des Trockenrückstands, des Feuchtigkeitsgehaltes und der Laborschüttdichte 65.080; Beuth Verlag: Berlin, Germany, 2008.

69. DIN EN 14775. Feste Biobrennstoffe-Bestimmung des Aschegehaltes 75.160.10; Beuth Verlag: Berlin, Germany, 2012. 
70. DIN EN 13039. Bodenverbesserungsmittel und Kultursubstrate-Bestimmung des Gehaltes an organischer Substanz und Asche; Beuth Verlag: Berlin, Germany, 2012.

71. DIN EN ISO 16948. Biogene Festbrennstoffe-Bestimmung des Gesamtgehaltes an Kohlenstoff, Wasserstoff und Stickstoff 75.160.10; Beuth Verlag: Berlin, Germany, 2015.

72. Boyle, W.C. Energy recovery from sanitary landfills-a review. In Microbial Energy Conversion, Proceedings of a Seminar Sponsored by the UN Institute for Training and Research (UNITAR) and the Ministry for Research and Technology of the Federal Republic of Germany; Schlegel, H.G., Barnea, J., Eds.; Elsevier Science: Burlington, VT, USA, 1977; pp. 119-138. ISBN 9780080217918.

73. Buswell, A.M. Anaerobic Fermentations. Available online: https://www.ideals.illinois.edu/bitstream/handle/2142/94555 /ISWSB-32.pdf?sequence=1 (accessed on 12 April 2020).

74. Sailer, G.; Eichermüller, J.; Poetsch, J.; Paczkowski, S.; Pelz, S.; Oechsner, H.; Müller, J. Optimizing anaerobic digestion of organic fraction of municipal solid waste (OFMSW) by using biomass ashes as additives. Waste Manag. 2020, 109, 136-148. [CrossRef] [PubMed]

75. Bertau, M.; Simbach, B.; Aubel, I.; Kiehle, R.; Kaiser, D.; Tröbs, R. Verbesserung der Klärschlammentwässerung durch den Abbau der Extrazellulären Polymeren Substanzen; Freiberg. 2018. Available online: https://www.dbu.de/projekt_32909/01_db_2409 .html (accessed on 23 May 2020).

76. Maier, J.; Scheffknecht, G. Systematische Untersuchungen zur Rückgewinnung von Phosphor aus Klärschlamm unter besonderer Berücksichtigung von Feuerungparametern. 2007. Available online: https:/ / fachdokumente.lubw.baden-wuerttemberg. de/servlet/is / 40276/BWT24004SBer.pdf?command=downloadContent\&filename=BWT24004SBer.pdf\&FIS=203 (accessed on 23 May 2020).

77. Sherwood, J. The significance of biomass in a circular economy. Bioresour. Technol. 2020, 300, 122755. [CrossRef] [PubMed]

78. Constantinescu, M.; Bucura, F.; Ionete, R.-E.; Niculescu, V.-C.; Ionete, E.I.; Zaharioiu, A.; Oancea, S.; Miricioiu, M.G. Comparative study on plastic materials as a new source of energy. Mater. Plast. 2019, 56, 41-46. [CrossRef]

79. Lansing, S.; Hülsemann, B.; Choudhury, A.; Schueler, J.; Lisboa, M.S.; Oechsner, H. Food waste co-digestion in Germany and the United States: From lab to full-scale systems. Resour. Conserv. Recycl. 2019, 148, 104-113. [CrossRef] 